\title{
FAKTOR-FAKTOR YANG MEMPENGARUHI POLA MENYUSUI PADA MASA PANDEMI COVID-19
}

\author{
${ }^{1}$ Universitas Muhammadiyah Lamongan \\ ${ }^{2}$ Universitas Muhammadiyah Lamongan
}

Andri Tri Kusumaningrum ${ }^{1 *}$, Ponco Indah Arista Sari ${ }^{2}$

Corresponding author:

Andri Tri Kusumaningrum

Universitas Muhammadiyah Lamongan

Email:

andri.trikusumaningrum17@gmail.com

\section{Article Info:}

Dikirim: 09 April 2021

Ditinjau: 20 April 2021

Diterima: 27 April 2021

DOI:

https://doi.org/10.33475/jikmh.v7i2.21

\begin{abstract}
A global pandemic or epidemic indicates that Covid-19 infection is so fast that almost no region in the world has been spared from the corona virus. It is hoped that the Covid-19 pandemic situation that occurs in Indonesia does not make postpartum mothers afraid of breastfeeding or stop breastfeeding. The government has made various efforts to stop the spread of the corona virus. One of the efforts to prevent the transmission of covid-19 is by implementing health protocols, including during breastfeeding. This study aims to determine the factors that influence breastfeeding patterns during the Covid-19 pandemic.The research design uses correlative analytic with a cross sectional approach. The study population was all breastfeeding mothers. The sample was taken using purposive sampling.Data collection used a closed online questionnaire for one month. Data analysis was in the form of bivariant analysis using the chi-square test, while multivariant analysis used multiple logistic regression tests (multiple regretion). The results showed that there were factors that had a significant relationship with the breastfeeding pattern of breastfeeding mothers during the Covid-19 pandemic, namely knowledge ( $p$ 0.001), attitude ( $p$ 0.005) and the results of multivariate analysis obtained a $p$ value of $0.001(\alpha<0.005)$ so that it is known that these variables had a real influence on breastfeeding patterns during the Covid-19 pandemic. Midwives in collaboration with health cadres are expected to increase educational efforts about breastfeeding information during the Covid-19 pandemic so that they can increase knowledge and change the attitudes and behavior of mothers for the better.
\end{abstract}

Keywords : Factors ; Breastfeeding pattern; Covid-19.

\begin{abstract}
Abstrak
Pandemi atau epidemi global mengindikasikan infeksi Covid-19 sangat cepat hingga hampir tidak ada wilayah di dunia yang terhindar dari virus corona. Situasi pandemi covid-19 yang terjadi di Indonesia, diharapkan tidak membuat para ibu nifas menyusui takut atau berhenti memberikan ASI-nya.

Pemerintah telah melakukan berbagai upaya untuk menghentikan penyebaran virus corona. Salah satu upaya pencegahan penularan covid-19 diantaranya dengan menerapkan protokol kesehatan termasuk pada masa menyusui. Penelitian ini bertujuan mengetahui faktor yang mempengaruhi pola menyusui pada masa pandemi covid-19. Desain penelitian menggunakan analitik korelatif dengan pendekatan cross sectional. Populasi penelitian seluruh ibu menyusui, pengambilan sample menggunakan purposive Sampling. Pengumpulan data menggunakan kuesioner tertutup secara online selama satu bulan. Analisa data berupa analisis bivariant menggunakan uji chi-square sedangkan analisa multivariante menggunakan uji regresi logistic ganda (multiple regretion). Hasil penelitian didapatkan terdapat faktor yang memiliki hubungan yang bermakna dengan pola menyusui ibu menyusui dimasa pandemi covid-19 yaitu pengetahuan (p 0,001), sikap (p 0,005) dan hasil analisa multivariate didapatkan nilai p $0,001(\alpha<0.005)$ sehingga diketahui bahwa variabel tersebut memberikan pengaruh nyata terhadap pola menyusui pada masa pandemi covid-19. Bidan bekerjasama dengan kader kesehatan diharapkan meningkatkan upaya edukasi tentang informasi menyusui dimasa pandemi covid-19 sehingga dapat meningkatkan pengetahuan dan merubah sikap serta perilaku ibu menjadi lebih baik.
\end{abstract}

Kata Kunci : Faktor-faktor ; Pola menyusui ; Covid-19. 


\section{PENDAHULUAN}

Pandemi atau epidemi global mengindikasikan infeksi Covid-19 yang sangat cepat hingga hampir tidak ada negara atau wilayah di dunia yang terhindar dari virus corona. Salah satu sektor yang terdampak yaitu ketahanan keluarga. Ketahanan keluarga dapat dijaga salah satunya dengan tetap menyusui pada masa pandemi. (Widaryanti Rahayu, 2021). Situasi pandemi Covid-19 yang terjadi di Indonesia, diharapkan tidak membuat para ibu takut atau berhenti memberikan ASInya. Saat ini pemerintah telah mengambil berbagai tindakan untuk menghentikan penyebaran virus corona. Salah satu upaya pencegahan penularan Covid-19 diantaranya dengan menghimbau masyarakat untuk menjaga jarak fisik minimal satu meter dengan orang lain. Namun hal ini malah membuat para ibu menyusui menjadi takut untuk menyusui bayinya. Situasi pandemi saat ini tentunya menjadi tantangan tersendiri bagi ibu menyusui. Sampai saat ini keberadaan virus Covid-19 pada ASI masih belum dibuktikan secara ilmiah. WHO (world Health Organization) masih merekomendasikan menyusui karena manfaat menyusui secara substansi melebihi potensi resiko penularan covid-19 (WHO, 2020). Akibat pandemi Covid-19, akses kepada layanan esensial seperti konseling menyusui di rumah sakit, klinik kesehatan atau melalui kunjungan rumah serta rumah sakit menjadi terganggu. Informasi tidak tepat yang beredar tentang keamanan menyusui telah menurunkan angka ibu menyusui karena para ibu takut menularkan penyakit kepada bayi mereka (Kemeskes.RI, 2020). Berdasarkan survey awal di desa Plosowahyu - Lamongan didapatkan dari 10 ibu menyusui di masa pandemi, $40 \%$ diantaranya menghentikan menyusui dengan mengganti susu formula, $40 \%$ mengurangi frekuensi menyusui dengan kombinasi susu formula, $20 \%$ tetap menyusui seperti biasa. Hal ini menunjukkan bahwa terjadi perubahan pola menyusui pada masa pandemi dan menurunnya angka menyusui.

Keberlangsungan menyusui pada masa pandemi dipengaruhi oleh berbagai faktor, diantaranya faktor pengetahuan. Pengetahuan mengenai Covid-19 tidak hanya dilakukan oleh yang terinfeksi. Semua pihak wajib memahami agar dapat melakukan upaya yang tepat untuk melindungi dirinya sendiri dan orang lain, termasuk pada ibu nifas dan menyusui. Ibu menyusui perlu memahami bagaimana tindakan yang tepat dalam mencegah penularan covid-19, sekaligus melindungi bayi dari potensi serangan covid-19. Kondisi pandemi membuat psikologis ibu menyusui menjadi khawatir jika menyusui dapat menularkan virus kepada bayinya. Faktor sikap, sikap ibu menyusui akan diikuti atau tidak oleh perilaku berdasarkan pengalaman langsung, karena sikap terbentuk dari pengalaman melalui proses belajar sosial. Melalui interaksi sosial dapat merubah pola pikir dan mempengaruhi ibu dalam menentukan sikap (Kemenkes.RI, 2020a). Kondisi pandemi covid-19 saat ini akan membuat ibu menyusui mengambil sikap berkaitan dengan upaya pengendalian dan pencegahannya terhadap potensi terjadinya penyebaran covid-19 terhadap bayinya selama proses menyusui (Kemenkes.RI, 2020b)

Pemberian ASI merupakan opsi terbaik untuk bayi dan anak terutama pada kondisi pandemi saat ini. Manfaat yang begitu besar bukan hanya untuk bayi, namun juga bagi ibu perlu dipahami dan diketahui oleh para ibu menyusui secara luas. ASI merupakan nutrisi terbaik untuk melindungi bayi dan balita dari berbagai penyakit termasuk pada masa wabah covid-19. Terdapat perlindungan imunologis yang terdapat di dalam ASI sehingga banyak ahli yang sepakat ibu menysui tetap harus menyusui selama masa pandemi covid-19. ASI merupakan campuran sempurna dari antibody, vitamin dan faktor kekebalan sehingga sangat dibutuhkan pada 
masa pandemi ini untuk meningkatkan kekebalan bayi.

Sehingga perubahan pola menyusui pada masa pandemic covid-19 perlu dipahami oleh ibu, diantaranya ; ibu yang diduga terinfeksi covid-19, yang memutuskan menyusui langsung di payudara harus memakai masker bedah dan mencuci tangan sebelum menyusui. Jika ibu memilih tidak menyusui langsung, harus mengenakan masker bedah dan mencuci tangan sebelum memompa atau memberikan ASI perah dan selama kontak dekat dengan bayi (Kemenkes.RI, 2020b). Berdasarkan uraian di atas, maka peneliti tertarik melakukan penelitian untuk mengetahui faktor yang mempengaruhi pola menyusui pada masa pandemi Covid-19.

\section{METODE PENELITIAN}

Desain penelitian dalam penelitian ini menggunakan analitik korelatif dengan pendekatan cross sectional. Populasi dalam penelitian ini adalah seluruh ibu menyusui di Desa Plosowahyu Kecamatan Lamongan. Pengambilan sample menggunakan purposive sampling sebesar 32 ibu menyusui 0-2 tahun. Pengumpulan data melalui koordinasi dengan bidan desa dan kader kesehatan Desa Plosowahyu-Lamongan. Pengukuran variabel pengetahuan, sikap dan pola menyusui menggunakan skala likert dilakukan menggunakan secara online selama satu bulan. Analisa data yang digunakan dalam penelitian ini berupa analisis bivariant menggunakan uji chi square sedangkan analisa multivariant menggunakan uji regresi logictic ganda (multiple regretion) (Nursalam, 2014).

\section{HASIL PENELITIAN DAN PEMBAHASAN}

1. Data Umum

a. Gambaran Umum Lokasi Penelitian

Penelitian ini di lakukan di Desa Plosowahyu meliputi RW 01, RW 02, RW 03 Kecamatan Lamongan Kabupaten Lamongan. Desa ini terbagi menjadi 3 dusun yaitu dusun Wahyu, dusun Plosogeneng dan dusun
Plalangan. Desa Plosowahyu sebelah utara berbatasan dengan Desa Turi, sebelah timur Desa Sukorejo dan desa Sukomulyo, sebelah selatan berbatasan dengan Desa tanjung dan desa Made dan sebelah barat desa Karangtapen. Plosowahyu mempunyai 1 ponkesdes dengan satu tenaga kesehatan bidan dan satu perawat yang dibantu oleh kader Kesehatan. Program KIA terdiri dari kelas ibu hamil, kunjungan nifas, posyandu balita, posyandu lansia dan taman posyandu yang dilaksankan rutin setiap bulan di tiap RW.

b. Karakteristik Responden

Karateristik ibu dalam penelitian ini meliputi umur, tingkat pendidikan, paritas, Informasi tentang menyusui di masa pandemi covid-19.

Tabel 1. Distribusi Karakteristik Ibu di Desa Plosowahyu Kecamatan Lamongan Kabupaten Lamongan Tahun 2021.

\begin{tabular}{lcc}
\hline Karakteristik & Frekuensi & Prosentase \\
\hline Usia & & \\
$<20$ Tahun & 0 & 0 \\
20-35 Tahun & 26 & 81,3 \\
$>35$ Tahun & 6 & 18,7 \\
Pendidikan & & \\
SMP & 18 & 56,2 \\
SMA & 12 & 37,5 \\
Diploma/PT & 2 & 6,3 \\
Pekerjaan & 13 & 40.6 \\
IRT & 8 & 25 \\
Petani & 6 & 18.8 \\
Swasta & 5 & 15.6 \\
Wiraswasta & & \\
PNS & 19 & 59,4 \\
Paritas & 8 & 25 \\
1 & 5 & 15,6 \\
2 & & \\
$\geq 3$ & & \\
Informasi & 4 & 12,5 \\
Menyusui & 28 & 87,5 \\
Ada & & \\
Tidak Ada & & \\
\hline & & \\
\hline
\end{tabular}


2. Data Khusus

Deskripsi Responden Berdasarkan Variabel Penelitian

Tabel 2. Deskripsi Responden Berdasarkan Variabel Penelitian

\begin{tabular}{lcc}
\hline \multicolumn{1}{c}{ Variabel } & Frekuensi & Prosentase \\
\hline Pengetahuan & 0 & 0 \\
Baik & 8 & 25 \\
Cukup & 24 & 75 \\
Kurang & & \\
\hline Sikap & & \\
Positif & 5 & 15,6 \\
Negatif & 27 & 84,4 \\
\hline Pola Menyusui & & \\
Tepat & 10 & 31,2 \\
Tidak Tepat & 22 & 68,8 \\
\hline
\end{tabular}

Berdasarkan tabel 2 dapat dijelaskan bahwa sebagian besar (75\%) mempunyai pengetahuan kurang tentang menyusui di masa pandemi covid-19 dan sebagian kecil (25\%) mempunyai pengetahuan cukup. Hampir seluruhnya $(84,4 \%)$ mempunyai sikap yang negative dan sebagian kecil (15.6\%) mempunyai perilaku positif. Sebagian besar $(68.8 \%)$ mempunyai perilaku pola menyusui yang tidak tepat di masa pandemi covid-19 dan hampir setengah atau (31.2\%) responden mempunyai perilaku pola menyusi yang tepat di masa pandemi covid-19.

Tabel 3. Hasil Analisis Bivariat

\begin{tabular}{lc}
\multicolumn{1}{c}{ Variabel } & P Value \\
\hline Pengetahuan & 0.001 \\
Sikap & 0.005 \\
\hline
\end{tabular}

Tabel 4. Hasil Analisis Multivarit

\begin{tabular}{lc}
\hline \multicolumn{1}{c}{ Variabel } & P Value \\
\hline $\begin{array}{l}\text { uji regresi logictic } \\
\text { ganda }\end{array}$ & 0.001 \\
\hline
\end{tabular}

\section{PEMBAHASAN}

\section{HUBUNGAN PENGETAHUAN TERHADAP POLA MENYUSUI PADA MASA PANDEMI COVID-19}

Berdasarkan hasil penelitian, dapat dijelaskan bahwa sebagian besar (75\%) mempunyai pengetahuan kurang tentang informasi menyusui di masa pandemi covid-19 dan sebagian kecil (25\%) mempunyai pengetahuan yang cukup. Hal ini menunjukkan masih sangat rendah pengetahuan ibu tentang pola menyusui yang aman pada masa pandemi covid-19. Berdasarkan hasil uji statistik didapatkan nilai $\mathrm{P}$ value $=0.001(<0.05)$ menunjukkan H0 ditolak, artinya faktor pengetahuan mempunyai pengaruh yang signifikan dengan pola perilaku menyusui di masa pandemi covid-19. Hal ini menunjukkan pengetahuan merupakan faktor yang mendukung ibu menyusui dalam perubahan pola perilaku menyusui di masa pandemi covid-19. Pengetahuan mengenai pola menyusui di masa pandemi covid-19 adalah hal-hal yang berkaitan dengan motivasi menyusui serta pengendalian dan pencegahan resiko penularan covid-19 selama proses menyusui. Berdasarkan penelitian (Amran \& Amran, 2013) mengungkapkan bahwa perilaku yang didasari pengetahuan yang baik akan lebih langgeng daripada perilaku yang tidak didasari dengan pengetahuan. Pengetahuan tentang menyusui di masa pandemi covid19 sangat penting untuk dipelajari karena informasi tentang pola menyusui di masa pandemi merupakan faktor internal yang mempengaruhi ketepatan perilaku menyusui selama masa pandemi covid-19. Menurut (Budiharto, 2016), pengetahuan seseorang mengenai suatu obyek akan menjadi tindakan terhadap obyek tersebut apabila pengetahuan itu disertai kesiapan untuk berperilaku sesuai dengan pengetahuan tentang obyek tersebut. Jika pengetahuan ibu menyusui tentang pengendalian dan pencegahan covid-19 baik, maka pola 
menyusui selama masa pandemi semakin tepat sesuai dengan protokol kesehatan.

Tingkat pengetahuan ibu menyusui dapat dipengaruhi dari tingkat pendidikan, paritas, informasi yang diterima. Hasil penelitian menunjukkan pendidikan ibu menyusui yaitu tingkat SMP atau sederajat sebanyak 18 responden atau (56.2) Lebih dari separuh pendidikan ibu termasuk pendidikan tingkat dasar yang mempengaruhi dalam kemampuan menerima informasi yang berpengaruh pada perilaku ibu. Melalui pendidikan dapat meningkatkan pengetahuan, menumbuhkan sikap positif serta memberikan atau meningkatkan keterampilan masyarakat atau individu tentang aspek-aspek yang bersangkutan, sehingga dicapai suatu masyarakat yang berkembang dengan generasi penerus yang cerdas. Generasi yang baik seseorang akan lebih mudah dalam menerima segala informasi dari luar (Marsiana Wibowo, 2016).

Paritas ibu menyusui menunjukkan bahwa sebagian besar paritas ibu 1 sebanyak 19 atau (59,4 \%). Persalinan pada ibu yang baru mempunyai 1 anak akan berdampak pada pola pengasuhan bayi terutama dalam proses menyusui. Ketrampilan dan motivasi menyusui masih kurang pada ibu yang baru mempunyai anak (Ariani, 2010). Hal ini juga akan mempengaruhi ketrampilan atau pola menyusui yang tidak tepat pada masa pandemi covid-19.

Hasil penelitian menunjukkan bahwa hampir seluruhnya $(87.5 \%)$ ibu belum pernah mendapat informasi tentang menyusui pada masa pandemi covid-19. Ini menunjukkan bahwa pengetahuan ibu menyusui masih sangat kurang sehingga mempengaruhi perilaku menyusui yang tidak tepat selama masa pandemi covid19. Pengetahuan kesehatan menjadi lebih baik dapat diperoleh melalui informasi pendidikan kesehatan yang dapat merubah perilaku hidup sehat (Notoatmodjo, 2012). Menurut (Samaria et al., 2020) dalam penelitiannya menunjukkan tingkat pengetahuan ibu cukup $(55,3 \%)$, pengetahuan cukup $(34,1 \%)$ dalam hal menyusui diera pandemi covid-19 yang kemudian setelah diberikan edukasi mengalami peningkatan tingkat pengetahuan tinggi (38,3\%) dan pengetahuan cukup (27,6\%). Hal ini sesuai menurut (Fitriani, 2011) pendidikan kesehatan merupakan upaya terencana untuk mengubah perilaku individu, kelompok maupun masyarakat yang merupakan perubahan cara berfikir, bersikap, dan berbuat dengan tujuan membantu pengobatan, rehabilitasi, pencegahan penyakit dan promosi hidup sehat.

\section{HUBUNGAN SIKAP TERHADAP POLA MENYUSUI PADA MASA PANDEMI COVID-19}

Berdasarkan hasil penelitian, dapat dijelaskan bahwa hampir seluruhnya $(84,4 \%)$ ibu menyusui mempunyai sikap negativ dan sebagian kecil $(15,6 \%)$ mempunyai sikap positif. Berdasarkan hasil analisa uji statistik didapatkan nilai $\mathrm{P}$ value $0.005(<0.05)$ menunjukkan $\mathrm{H} 0$ ditolak, artinya faktor sikap mempunyai hubungan yang signifikan dengan pola perilaku menyusui ibu pada masa pandemi-covid-19.

Sikap merupakan kesediaan ibu untuk bereaksi terhadap obyek tertentu sebagai bentuk penghayatan dengan menerima, merespon, menghargai

dan bertanggungjawab (Azwar, 2016). Terbentuknya sikap karena adanya interaksi manusia dengan oyek tertentu (komunikasi) serta interaksi sosial di dalam maupun diluar kelompok. Interaksi diluar kelompok bisa dilakukan melalui media komunikasi seperti televisi, buku, majalah. Dikemukakan pula, media massa mempunyai pengaruh besar dalam membentuk atau mengubah sikap pada orang banyak namun hal tersebut tergantung dari isi komunikasi dan sumber informasi (Fatwiany, 2020). Kondisi pandemi covid-19 saat ini akan membuat ibu menyusui mengambil sikap 
Kusumaningrum, A. T., Sari, P.I.A.. (2021).

berkaitan dengan upaya pengendalian dan terhadap pola perilaku ibu menyusui di masa pandemi pencegahannya terhadap potensi terjadinya penyebaran covid-19 terhadap bayinya selama proses menyusui. Sikap ibu menyusui akan diikuti atau tidak oleh perilaku berdasarkan pengalaman langsung, karena sikap terbentuk dari pengalaman melalui proses belajar sosial. Melalui interaksi sosial dapat merubah pola pikir dan mempengaruhi ibu dalam menentukan sikap. Hasil penelitian para ahli menunjukkan bahwa terdapat hubungan yang kuat antar sikap dengan tindakan. Sikap (attitude) sangat besar pengaruhnya dalam kehidupan manusia. Sikap sangat menentukan tindakan (behavior) seseorang (Ratna Prahesti, 2018). Sikap sangat mempengaruhi tanggapan seseorang terhadap masalah kemasyarakatan termasuk masalah dalam menyusui di masa pandemi covid-19. Seseorang yang mempunyai sikap positif terhadap suatu obyek, besar kemungkinan mempunyai niat untuk bertindak positif juga terhadap obyek tersebut dan timbul sikap positif tersebut didasari oleh adanya pemikiran dan pengetahuan terhadap obyek tersebut. Sikap mempunyai motivasi yang berarti ada segi kedinamisan untuk mencapai tujuan. Ibu menyusui dengan sikap positif terjadi kesiapan mental dalam diri dalam menghadapi kondisi pandemi, akan cenderung melakukan tindakan pola menyusui yang tepat dalam pengendalian dan pencegahan penyebaran covid-19, melakukan berbagai upaya agar bagaimana proses menyusui tetap berlangsung dan bayinya tetap sehat dan aman dari potensi penularan covid-19.

\section{FAKTOR-FAKTOR YANG MEMPENGARUHI POLA MENYUSUI PADA MASA PANDEMI COVID-19}

Berdasarkan hasil penelitian, uji statistik analisa multivariate didapatkan nilai $\mathrm{P}$ value $=0.001(<0.05)$. Yang dapat diinterpretasikan bahwa variabel pengetahuan dan sikap memberikan pengaruh signifikan

covid-19.

Dijelaskan dalam (Ahmad, 2012), menyebutkan bahwa terdapat tiga komponen yang mempengaruhi perilaku manusia, yaitu komponen kognitif, afektif dan konatif. Komponen kognitif merupakan aspek intelektual yang berkaitan dengan apa yang diketahui manusia. Informasi dari luar, seperti pendidikan tentang kesehatan, media massa dapat merubah perilaku untuk hidup sehat. Skinner (1938) dikutip oleh (Notoatmodjo, 2012), merumuskan bahwa perilaku merupakan respon atau reaksi seseorang terhadap stimulus (rangsangan dari luar). Oleh karena perilaku ini terjadi melalui proses adanya stimulus terhadap organisme, kemudian organisme tersebut merespon. Ibu menyusui yang dihadapkan pada masa pandemi covid-19 saat ini merupakan stimulus, diharapkan ibu dapat melakukan perubahan pola menyusui yang tepat yang sesuai dengan protokol kesehatan sebagai upaya pengendalian dan pencegahan penyebaran covid-19 selama proses menyusui, karena manfaat menyusui jauh melebihi dari potensi penularan covid-19.

Sedangkan menurut Lawrence Green dikutip dari (Notoatmodjo, 2012), mencoba mengenali perilaku manusia berangkat dari tingkat kesehatan. Kondisi status kesehatan ibu menyusui mempengaruhi perilaku kewaspadaan ibu terhadap upaya pencegahan penularan covid-19 kepada bayinya. Kesehatan seseorang atau masyarakat dipengaruhi oleh dua faktor pokok yaitu faktor diluar perilaku (Non Behaviour Causes) dan faktor didalam perilaku (Bahaviour Causes). Faktor perilaku tersebut dipengaruhi oleh faktor predisposisi (Predisposing Factor) yang terwujud dalam pengetahuan, sikap, keyakinan, nilai-nilai dan sebagainya. Faktor pendorong (Reinforcing Factor) yang terwujud dalam sikap dan perilaku petugas kesehatan atau petugas yang lain yang merupakan 
kelompok referensi dari perilaku masyarakat. Sikap dan perilaku petugas kesehatan dalam hal ini memberikan dukungan dengan memberikan edukasi pola menyusui pada ibu selama pandemi covid-19. Faktor pendukung (Enabling Factor) yang terwujud dalam lingkungan fisik, tersedia atau tidaknya fasilitas atau sarana kesehatan misalnya obat-obatan, peralatan steril, ruang perawatan dan sebagainya (Budiharto, 2016). Kondisi pandemi covid-19 dapat menurunkan frekuensi kunjungan ibu nifas dan menyusui ke pelayanan kesehatan untuk mendapatkan akses pemeriksaan maupun hal edukasi tentang menyusui, sehingga mempengaruhi pola pikir dan perilaku ibu selama masa menyusui diera pandemi covid-19.

\section{KESIMPULAN}

Pengetahuan ibu menyusui sebagian besar (75\%) mempunyai pengetahuan kurang tentang dan sebagian kecil (25\%) mempunyai pengetahuan cukup pola menyusui dimasa pandemi covid-19. Sikap ibu menyusui hampir seluruhnya $(84,4 \%)$ mempunyai sikap negative dan sebagian kecil (15.6\%) mempunyai sikap positif. Faktor pengetahuan mempunyai hubungan yang signifikan dengan pola menyusui dimasa pandemi covid-19 ditunjukkan hasil uji statistik didapatkan nilai $\mathrm{P}$ value $=0.001(<0.05)$. Berdasarkan hasil analisa uji statistik didapatkan nilai $P$ value $0.005 \quad(<0.05)$ menunjukkan H0 ditolak, artinya faktor sikap mempunyai hubungan yang signifikan dengan pola menyusui ibu dimasa pandemi-covid-19. Hasil uji statistik analisa multivariate didapatkan nilai $\mathrm{P}$ value $=$ $0.001(<0.005)$. Artinya bahwa variabel pengetahuan dan sikap memberikan pengaruh signifikan terhadap pola ibu menyusui dimasa pandemi covid-19.

\section{UCAPAN TERIMA KASIH}

Peneliti mengucapakan terima kasih yang sebanyakbanyaknya kepada Rektor dan Kepala LPPM Universitas Muhammadiyah Lamongan yang telah memberikan ijin penelitian dan memberikan fasilitas. Serta ucapan terimakasih kepada bapak kepala desa dan bidan Desa Plosowahyu yang telah memberikan ijin tempat penelitian dan memfasilitasi selama pengumpulan data.

\section{DAFTAR RUJUKAN}

Ahmad, K. (2012). Promosi Kesehatan Dengan pendekatan Teori Perilaku media dan aplikasinya (Perpustaka). Rajawali Pers.

Amran, Y., \& Amran, V. Y. A. (2013). Gambaran Pengetahuan Ibu Tentang Menyusui dan Dampaknya Terhadap Pemberian ASI Eksklusif Mothers Knowledge about Breastfeeding and Its Impact on Exclusive Breastfeeding. Jurnal Kesehatan Reproduksi, 3(1),

52-61.

http://ejournal.litbang.depkes.go.id/index.php/kes pro/article/viewFile/3930/3773

Azwar, S. (2016). Sikap Manusia Dan Pengukurannya. Pustaka Pelajar.

Budiharto. (2016). Pengantar Ilmu Perilaku Kesehatan dan Pendidikan Kesehatan Gigi (II). EGC.

Fatwiany. (2020). Hubungan Pengetahuan Dengan Sikap Ibu Nifas Tentang Kunjungan Nifas Pada Masa Pandemi Covid 19 Di Kelurahan Tj. Gusta Kec. Medan Helvetia. Jurnal Ilmiah Simantek, 45(Supplement), S-102.

Fitriani, S. (2011). Promosi Kesehatan. Graha Ilmu.

Kemenkes.RI. (2020a). Apa Yang Harus Dilakukan Masyarakat Untuk Mencegah Penularan Covid19? Germas, Kementrian Kesehatan Republik Indonesia. 
Kemenkes.RI. (2020b). Pedoman Pencegahan dan

Pengendalian Coronavirus Disease (COVID-19).

Direktorat Jenderal Pencegahan dan Pengendalian Penyakit.

Kemeskes.RI. (2020). Pedoman bagi Ibu hamil,

Bersalin, Nifas, dan Bayi Baru Lahir. Kementrian

Kesehatan Republik Indonesia.

Marsiana Wibowo. (2016). Jurnal Kesehatan

Masyarakat Andalas. Dukungan Informasi Bagia

Ibu Menyusui Dalam Memberikan ASI Eksklusif

Di Kecamatan Gondokusuman, Yogyakarta, 11(1), $87-95$.

Notoatmodjo, S. (2012). Promosi Kesehatan dan Perilaku Kesehatan. Rineka Cipta.

Nursalam. (2014). Manajemen Keperawatan: Aplikasi

Dalam Praktik Keperawatan Profesional. Salemba Medika.

Ratna Prahesti. (2018). Sikap Ibu Menyusui Dalam

Pemberian Asi Terhadap Keberhasilan Asi

Ekslusif Di Puskesmas Kota Gede I Yogyakarta

Tahun 2017. Jurnal Kesehatan Madani Medika, 9(1), 71-75. https://doi.org/10.36569/jmm.v9i1.30

Samaria, D., Alita, R., \& Marcelina, L. A. (2020).

Pengaruh Paket Edukasi Laktasi Sayang Ibu Dan

Anak Di Era Pandemi Covid-19 Terhadap

Pengetahuan Ibu Menyusui Di Kabupaten Lebak,
Pendahuluan. Indonesian Journal of Nursing

Health Science, 5(2), 134-141.

WHO. (n.d.). Menyusui di Masa Pandemi.

Widaryanti Rahayu. (2021). Pendampingan Ibu Menyusui Pada Masa Pandemi COVID-19 Guna Menjaga Ketahanan Keluarga. Jurnal Kependudukan, Keluarga, Dan Sumber Daya Manusia Volume 2, No. 1, Tahun 2021, 1 - 8 ISSN 2716-2036 (Online)

DOI 10.37269/Pancanaka.V2i1.85

Pendampingan, 2(1), 1-8.

https://doi.org/10.37269/pancanaka.v2i1.85

Cite this article as: Kusumaningrum, A. T., Sari, P.I.A. (2021). Faktor-faktor Yang Mempengaruhi Pola Menyusui Pada Masa Pandemi COVID-19. Jurnal Ilmiah Media Husada. 10(1), 7481. https://doi.org/10.33475/jikmh.v7i2.21 